Annales Missiologici Posnanienses t. 23 (2018), s. 41-54

doi: 10.14746/amp.2018.23.3

KATARZYNA ANNA MICH

Uniwersytet Kardynała Stefana Wyszyńskiego w Warszawie

Wydział Teologiczny

\title{
Elements of Christian popular piety in Nubia (VI-XVI century) - an outline of aspects
}

Faith must be rooted within the given community's culture, for if it does not filter through it may, due to both internal and external factors, face its downfall - for the believers may experience it superficially.

Nubia has been officially incorporated into the Christian family as early as the $6^{\text {th }}$ century and was an important centre of Christian culture, despite the fact that it has been forgotten and existed in isolation. Today the uniqueness of this christianity is proven solely by archeological sources and rare epigraphical sources, which preserve its lifespan and splendor. Yet, despite possessing its own religious culture, forms of expressing the liturgy and art it fell and was forgotten (Atiya 427-441).

\section{Popular piety of laity as elements of cultural identity of Christianity}

An attempt to understand whether Christianity has penetrated a given culture, whether it was an element culturally alien may bring much light to understanding the reasons of the downfall of a given church. Research on the question of nativity - meaning the incorporation into local culture - of Christianity are multi-faceted and apply to primarily the process of incorporating a new religion into the local culture via liturgy, liturgical language, the worship of saints, local elements included in architecture and the furnishing of churches and forms of popular piety (Mich 73-75). They are essential for the fruitful experiencing of the faith by secular believers, whom - more often than not - did not have the means to understand the liturgy in which they took part. It was solely via the popular piety that they were able to commune with the sacrum. 
Popular piety is an authentic mean to experience spiritual both during the liturgy and service outside it, and in everyday life - creating a peculiar 'native liturgy'. The everyday life of the believers is being penetrated by the popular piety shaped considerably by the native vision of the world.

The common folk, often unaware of the religious doctrine, often interprets the articles of christian faith in their own way (Araszczuk 163-164). Since the very beginning of Christianity, the popular piety has been developing simultaneously with liturgical piety, resulting in a peculiar native religious consciousness, displayed in particular piety practices (Kopeć 26-31).

Popular piety consists of, in the light of the modern definition, various cultural manifestations, both public and private, which within the christian faith bear forms stem from the spirit of given nations or social groups and their culture. They are derived from the outside stance of faith and and are an expression of an idiosyncratic connection of the believers with the Divine Persons, Holy Mother and the saints (cf. DPLandL, 8 and 9).

There are not many epigraphical sources, which could help in reconstructing the popular piety in Nubia. The elements introduced in this article are merely an outline of popular piety which, due to research of sites of settlements from the period of the Christian kingdoms, id being reconstructed. It seems that certain elements of popular piety might have survived in the customs of modern Nubian community (Vantini 25-39).

\section{Christianity in Nubia}

On the wreckage of the mighty Kingdom of Meroe between the $5^{\text {th }}$ and $6^{\text {th }}$ century the Nubian tribes created three state organisms of their own. Nobatia was created between the first and third Cataract, with a capital situated in Pachoras. On the north its neighbor was Makuria developing around Old Dongola. On the southend of Nubia, by the Blue Nile, the kingdom of Alwa (Alodia) was formed, with the city of Soba as its main centre (Welsby 14-30).

The beginning of Christianity in Nubia reach much earlier than the official Christianisation of the Nubian kingdoms, which took place during the $2^{\text {nd }}$ half of the $6^{\text {th }}$ century by the hand of the evangelists send by the Byzantine Empire (Dijkstra 2005).

According to written sources the Christianisation of the Nubian kingdoms took place in 3 stages. The northern kingdom of Nobatia was the first to experience the mission activity of the missionaries send by Constantinople (Frend 1975). Nobatia was the first to be christianised by the mission lead from Egypt, which was sponsored by the empress Theodora and accepted baptism by the Monophysitistic doctrine probably around the year 543. On the other hand, 
Makuria was christianised by the mission send by the emperor Justinian and was christened in accordance with the Chalcedonian (melkite) doctrine. Alwa was the last to undergo Christianisation by the Monophysisical missionaries from Nobatia, it is assumed that the ruler of Alwa accepted baptism around 580 (Welsby 31-68).

Due to the inclusion of the Eastern Roman Empire into the Christian world the Nubians adapted both the structure of the country, some cultural paradigms: language used both in administration, diplomacy and liturgy and the courtly outlook on life. The Byzantine influences were also present in art and architecture, the saints stemming from the Byzantine cultural circle were worshipped (Frend 1968).

Starting at the end of the $5^{\text {th }}$ century Nubia was experiencing a long-lasting period of evangelization of the Nubian people, which appears a process much more complicated than converting the king and his closest surroundings. New temples adapted for Christian cult were built (Welsby 35-38). The walls of the temples were decorated with murals depicting both biblical scenes from the Old and New Testament often supplemented with elements of apocryphal scriptures, saints, and also portraits of bishops and kings under the saint's protection (Zielińska 2010). They were to deepen faith and visualize new content.

Including the Nubian countries into the christian family stabilised the situation by the southern Egyptian border. Those kingdoms retained political independence and never became provinces of the Byzantine Empire.

The reasons of the unification of Makuria and Nobatia by the end of the $7^{\text {th }}$ century by the Makurian king Merkurios and why the monophysitistic doctrine became the dominant one in the United Kingdom (Adams). Christianity in Makuria was subject to the authority of the Monophysitistic Patriarch in Alexandria. The official contacts with Alexandria were most probably kept until Christianity was completely ousted from Nubia by Islam. By contrast, south from the fifth Cataract the self-reliant Kingdom of Alwa existed.

The period of intense relations with the Byzantine Empire in the years 542-641 related especially with evangelization was interrupted by the Arabian invasion to Egypt, which caused the separation of that province from the Empire (Welsby 68). However, the influence of the Byzantine in Nubia remained strong and throughout the entire period of the Kingdom of Makuria existence they were recorded in iconography, hymnography and sacral architecture (Burstein).

In the period between the $7^{\text {th }}$ and $13^{\text {th }}$ centuries Christianity in the United Kingdom of Makuria went through an incredible heyday. Numerous churches with paintings were created, convents and sanctuaries were thriving (Welsby 68-82). Among the numerous iconographic motifs known from other Christian centres in Nubia unique ones were discovered, such as the coronation of 
archangel Michael in the Monastery of Holy Trinity in the Makurian capital Dongola (Łaptaś 2008b, 76-77), and the depiction of a woman in a crown of thorns in Faras (Michałowski 125).

The liturgy was acquired from the Byzantine Empire and was practiced in Greek (Brakman), only a part of the liturgy and the Bible were translated into Nubian, written in the Coptic form of the Greek alphabet (Iliffe 42). The liturgy was incomprehensible to the believers, who were using the Nubian language.

Apocrypha were known, and they were apparently present in the official teachings of the Church - the motifs present in apocryphal scriptures are present on paintings in churches.

However along with the crisis of sovereignty in the Kingdom of Makuria, Christianity started to weaken. Soon after the fall of the Nubian kingdoms it fades between the $15^{\text {th }}$ and $16^{\text {th }}$ centuries (Welsby 2002, 242-258). Also, groups of Christians left without the care of clergymen that existed for the next several dozens of years were confirmed. Churches were abandoned, and then used as shelter for people and animals. That however did not save them from being buried by the desert sands (Lajtar 2008, 323). The Christians were very swiftly assimilated with the Muslims because Islam was not a threat to them. Despite the war fought by Nubians with the Islamic Egypt, and the Muslim rulers of Egypt moved in the internal matters of their kingdom during the power struggle, but they never experienced oppression from the hands of Muslims. The new religion was so attractive, that the gradual conversion of the kingdom to Islam was observed, which was carried out in a profoundly peaceful fashion (Martens 2015, 249-265).

\section{Laity in Nubia and elements of popular piety}

Research on the reconstruction of the Nubian popular piety is being constricted mainly by the scant number of written sources essential for understanding popular piety. There are also archeological sources from the research thus far which show that Christianity in Nubia was in possession of various forms of both liturgical piety and popular piety, often including elements of magic and syncretic.

An element characteristic to Nubian piety was the cult of archangels and angels, the heavenly intermediaries between the believers and God. It appears that to the Nubian Christians in the Valley of the Nile God was someone very distant, so they needed archangels, angels and saints to stand up for them. They had very important function in Nubian popular piety, for they were close to the people, who could address them directly (Łaptaś 2010, 675-682). 
Nubian piety was very reliant on the Byzantine, courtly prehension of life. Hierarchy was present and was unable to meet the emperor directly, an intermediary was needed to introduce one into the presence of a higher power. The Nubians saw the heavenly court based on the Byzantine court - with the existence of intermediaries, who even brought the believers to the Last Judgement after death. Archangels and angels were thus close to the people, for they could be addressed directly to stand up for them to God.

It might be assumed that the believers possessed no personal relation with God and all the prayers to Him were directed through the saint intermediaries.

For the Nubian believers the main intermediaries were the archangels. In Nubia seven of them are authenticated by name, they also held a tutelary function. In the Nubian inscriptions they are called the ambassadors at the Lord's Court, like „Michael archistrategos of angels, ambassador of God, announce me [to the Lord] in church in Sonqi Tino" (Donadoni 1975, 37). Apart from Michael, Rafael i Gabriel the Nubians were also familiar with Uriel, Iael and Zadekiel (Lajtar 2009,115-119). Michael, Rafael and Gabriel were the ones depicted most often in iconography and epigraphy. Some lone depictions of Zedekiel and Uriel are also known. (Łaptaś 2005, 53). In Nubia the archangels, especially Michael, were mighty guardians of humanity, who were able to effectively eradicate demons.

The secular, men and women both, were the ones to found churches and the paintings inside them (Łajtar and van der Vliet 1998). Church architecture suggests that the liturgical role of the laity diminished with time (Iliffe 42). It has been noted, that the naos intended for the believers was made considerably smaller, and the sanctuary zone becomes more and more concealed from the believers, like cathedral in Faras (Godlewski 2006).

Some historians attribute the ultimate disappearance of Nubian Christianity to a failure to adapt as fully to the local culture. In Nubian paintings the faces of Christ, His Mother and various saints were depicted in white in contradiction to the Nubians, which without a doubt had an influence on the adaptation of Christianity in local culture. It is worth noting that in the neighbouring Ethiopia, where Christianity was also existing in isolation there was no such contradistinction (Iliffe 42).

\section{- holy times}

So far, the known sources do not allow the pinpointing of practices in popular piety connected with experiencing saint liturgical periods such as the Advent, Nativity of Jesus, Lent nor the Passover period. They were most probably very similar to those known in the Coptic Egypt and the Byzantine Empire at that time (see Gerstel and Talbot). 
The believers were aided in their experiencing of the secrets of liturgical periods by paintings depicting events from the history of salvation - the Incarnation and Redemption. On the eastern wall of the northern nave a very popular theme was the Nativity scene, in which elements of canonical gospel intermingle with those from apocryphal scriptures. The southern naos (nave) was decorated with scenes from the passion cycle including the Harrowing of Hell, descent from the cross, the women at the tomb and monumental depictions of Christ in Majesty and the True Cross held up or adored by angels (Martens-Czarniecka 2012b).

The often depiction of the cross in churches in Nubia (such as Maiestas Crucis) and the remaining fragments of hymns dedicated to the cross indicate its cult (Dobrzyniecki; Grillmeier 286-289).

Fragments of hymns referring to Lent and Christmas are known, yet the singing in the liturgy was performed in Greek (Deptuła 2012).

\section{- the cult of Mother of God}

The cult of the Mother of God had an important place in the religious lives of the Nubians, it is confirmed by numerous paintings in churches and invocation inscriptions. The inscriptions by her depictions label her as Saint Mary

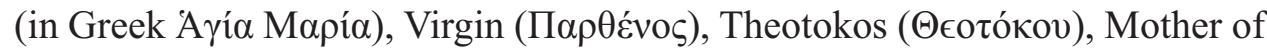

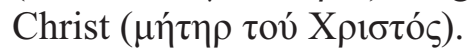

The depiction of Mother Mary with Child underwent many a change in Nubia throughout the centuries. It is especially visible in the Faras paintings, where she was depicted as Hodegetria - the Guide - Mary holding the Child while pointing to the Son (Jakobielski et al. cat. 1, 2, 30), Eleusa - the Merciful - with her Son nestled against her cheek (Jakobielski et al. cat. 130, 141), Regina - Mary depicted in royal robes and crown as the queen of heavens (Jakobielski et al. cat. 141), Galaktotrophousa - nursing (Jakobielski et al. cat. 74, 80).

A distinctive variant is the depiction of the Mother of God nursing and spinning at the same time, which is the merging of the Galaktotrophousa type with the depiction known from the Annunciation scenes known from Old Dongola (Martens-Czarnecka 2012a, 172). However, the depiction of Mother Mary of the Theotokos Orans (praying) type in Banganarti is, according to Żurawski $(2012,328)$ unique.

The images of God-Bearer depicted the idea of the Incarnation of God's Word, indeed born in the human body of the Mother, was real, visible and touchable. What was also underlined was her role in Redemption, for due to her consent to Incarnation the saving of mankind was performed. Yet there are no known depictions of the Mother by the Cross nor of the Pieta. 
The numerous images of the Mother of God in scenes of protection show, that she enjoyed a distinctive cult among Nubian Christians. Kings, their mothers and bishops, rich believers were often depicted in the presence of the Holy Mother holding the Child (Jakobielski et al. cat. 34, 49, 59, 71, 95, 109, 125, $138,141,148)$. Though the source of these depictions appears to be the motifs proclaiming authority derived from the Byzantine iconography, yet they express faith in Her unique mediation.

To the secular believers the Mother of God was above all else a guardian and an intercessor. A painting depicting Nubians dancing in front of an image of Mary bears a particular meaning for nubian Marian devotions in a monastery in Dongola (Martens-Czarniecka 2012a, 233-238).

\section{- Christian burial and intercessory prayers}

Christianity introduced a unification of forms of burial in Nubia. As soon as in the first years after the Christianisation began a decline of burial mounds is observed (elite graves characteristic to the period of shaping the Nubian statehood after the fall of the Meroe Empire) in favour of Christian burials (Drzewiecki 2016, 12). Graves were positioned on a East-West axis. The dead were placed in the erect position, with their heads exclusively towards the West, their hands alongside their body, which was connected to the Christian eschatology. A Nubian burial custom was to shield the head of the buried with two bricks placed on the side. With time several differences occurred: the dead were buried in elite graves, often in churches and monasteries or in special tombs made of dried or fired brick (Welsby 48-63). An outstanding discovery were the burials of monks in the monastery at Ghazali, where several monks were buried in unnatural positions and their bones bore trace of incisions made post-mortem (Stark and Ciecielska).

Although Christian graves in Nubia were devoid of grave goods, yet in Faras in the graves of bishop Ioannes and his successors dating back to the $10^{\text {th }}-11^{\text {th }}$ century 14 objects were found, among them two amphoras, water vessels, oil lamps, a pitcher, a cross and a spindle whorl (Dzierżykraj-Rogalski 36-38). Also, in the graves dating back to the $14^{\text {th }}$ century in Faras there were vessels, lamps and a cross made of bronze. The presence of lamps has a very simple explanation - their purpose was to get rid of the oxygen from the crypt slowing down the decomposition of bodies (Mierzejewska 92-93). However other objects, especially the vessels may make one doubt the orthodoxy of the Christian faith in Nubia. The water in the vessels was to restore and cool the dead during their journey to the Last Judgement (Mierzejewska 93).

Epigraphical sources confirm that the dead were surrounded with prayers and pleadings - so that God lets them rest in heaven. In the surviving prayers 
God is addressed directly, ignoring the mediation of others, which is a very profound element of Nubian piety.

The prayers for the dead were placed in epitaphs in Greek and Coptic.

Nubian epitaphs of the bishops in Faras include short prayers for the dead, such as those on bishop Ignatios stele from the year 802, addressing God in Greek, the liturgical language of the Nubian church. The prayer is a variant of an old prayer for the dead from the pre-chalcedonian period included in the Euchologion Mega (Jakobielski 1972, 71):

„Lord of Heaven and earth, God of spirits and all flesh, Lord of lords, God of all consolation, You who have defeated death and trodden down hell and given life to mankind, God of the Fathers, repose of the oppressed, rest his soul in a shining place. Amen" (following: Mierzejewska 98).

Another prayer from a stele of an unknown dead bearing the popular in Roman Egypt name Kolluthos includes a prayer consisting of fragments of Psalm 50 and the so-called Maness Prayer, a Jewish text dating back to the $2^{\text {nd }} / 1^{\text {st }}$ century $\mathrm{BC}$ incorporated into the Liturgy of St Mark performed in Nubian churches (Mierzejewska 100):

„Have mercy on me, O God, according to Thy great mercy.

And according to the multitude of Thy tender mercies blot out my iniquity!

Do not destroy me along with my transgressions,

Do not be angry with me forever,

Do not keep my bad deeds in your memory" (following: Mierzejewska 100)

In Nubia prayers for the dead were also said during the Liturgy of St Basil, during which the believers asked God asked God to grant the deceased souls eternal rest in the bosom of their Patriarchs (Mierzejewska 102). Its fragment can be found in the epitaph of bishop Maththaios who held that function from 730 to 766 (Jakobielski 63). A similar prayer can be found in the epitaph of bishop Stefanos, who died in 926 (Mierzejewska 104) and the epitaph of archbishop Georgios from Dongola, who died in 1113 (Eajtar and van der Vliet 2018, 19-20).

[...] „O God, give rest to his soul in the bosom of Abraham, Isaac and Jacob, in place from which pain and grief hans flown away, in the brilliancy of Your saints, amen. [...]". (following: Mierzejewska 102).

- Peregrinatio nubiana - sanctuaries in Nubia

Pilgrimaging was one of the elements of popular piety in Nubia. It is a typical form of popular piety. Pilgrimaging to places marked by the distinctive 
presence of the sacrum and is, essentially, an act of cult expressed through participation in liturgy, adoration and worship of God. Pilgrimaging has primarily a thankful and imploring aspect (Ostrowski 216-218). The beginnings of pilgrimage in Nubia date back to the pre-Christian era when the rulers of Meroe and after them the rulers of the forming Nubian kingdoms pilgrimaged to the temple of Isis on Philae island on Egypt (Dijkstra 2008).

The tradition of pilgrimaging was also strong during the existence of Christian kingdoms in Nubia, yet detailed reconstruction is obstructed due to lack of written sources essential for researching popular piety and tradition of pilgrimage destinations. Professor Bogdan Żurawski (2005: 301-302) reckons that 'many of the known and published archeological sites in Nubia dating back to the period when Christian kingdoms existed can be confidently called pilgrimage locations.' Such locations of particular attention for Nubian Christians might have been sites such as Tamit, Selib, Banganarti, Soba.

A very significant spot on the pilgrimage map of Nubia, where Nubian Christians headed to for cult purposes was the centre in Banganarti (in Nubian island of locust), situated on the right bank of the Nile, $10 \mathrm{~km}$ south from the capital of the kingdom of Makuria - Dongola (Żurawski 2012, 2014). In the light of the archeological and epigraphical research conducted so far under Bogdan Żurawski PhD, a professor at the Polish Academy of Sciences, since 2002, it can be stated that the Upper Church in Banganarti probably since the end of the $11^{\text {th }}$ century held a function of a pilgrimage church dedicated to archangel Raphael (Żurawski 2014, 106-120). The Rafaelion was a place of remarkably active pilgrim movement, which had to be connected to either the relics it was housing or the healing that took place there (Żurawski 2008, 317).

It needs to be noted, that among the problems the people of the desert face are eye diseases and blindness. For the religiosity and forming of popular piety among Nubians it was probably a sanctuary devoted to the archangel, who brought back the sense of sight to old Tobiah. The reference to the biblical tale of Tobiah and archangel Raphael are confirmed by inscriptions left by pilgrims in local Nubian and Greek. The significance of the place for popular piety is further confirmed by hundreds of inscriptions engraved on the walls of the church in Banganarti (Lajtar 2008).

It is not only the person of archangel Raphael may indicate the healing function of that holy in the eyes of Nubians place. An essential meaning to Nubian piety was carried by images of saint Cosmas and Damian, anargyroi, two Roman physicians from the 3rd century, who healed people and won them over for Christ. The believers believed that after death due to their intercession they will be able to obtain many graces (Laptaś 2004, 248). Images of those saints were also found in the Church of Angels in Tamit and in the so called 
Western Annex by the Monastery of the Holy Trinity in Dongola (Żurawski 1992, 423-448).

On seven chapels on the Eastern side images of the Nubian ruler under the care of archangel Raphael surrounded by the 12 apostles. It is therefore quite possible, that archangel Raphael also held the function of patron of the Nubian dynasty. It is also worth noting that the royal church in Dongola was also dedicated to archangel Raphael. Thus, it seems that Banganarti might have been a mausoleum of Makurian rulers.

The tradition of pilgrimage in Nubia is also most likely connected with the ritual of incubation, which can be confirmed by porticos by the churches. Pilgrims waited in queue for the possibility to spend a longer period in a sanctuary in order to experience direct closeness of the sacrum and attain healing (Żurawski 2014: 241-246).

It is also an attested pilgrim spot in honour of saint Menas at Selib, where prayers directed to the saint were found on church walls (Deptuła 2015) and numerous remnants indicating that believers pilgrimaged to Selib, perhaps it was a stop on the way to Bangatari and the capital of Makuria.

\section{- „, saint signs” on everyday objects}

Nubian popular piety is strongly affected by protection against evil demons constantly lay in wait for people. Faith in the activities of evil forces and demons was and still remains deeply rooted within the mentality of the inhabitants of the valley of the Nile (Żurawski 1992, 100).

In fragments of numerous ceramic vessels carved or painted on writings are visible. The most frequent being the name of archangel Michael written in Greek MIXAH $\Lambda$ (sometimes in a shorter form MXH $\Lambda$ or just in the form of a cryptograph $\mathrm{X} \Pi \Theta$ or a monogram), and also archangel Raphael, the first letters of the old testament Four Living Creatures: Meliton, Paramyra, Agrammatap, Peiouruthion written as МПАП (Mierzejewska 252-257). Archbishop of Alexandria Timothy wrote about the custom of writing the name of archangel Michael on Nubian house walls for protection and also placing it on the bottom of robes in a speech in honour of the archangel preserved in Coptic. The signs were protected Christians from enemies and dangers. A monogram of archangel Michael was found also on the inside of a thigh on a mummy of a woman who lived around the year 700 in the region of the $4^{\text {th }}$ cataract (Vandenbeusch and Antoine).

The holy signs were also to protect from demons entering while using the toilet, for the holy symbols such as monograms of archangels were carved into those ceramic appliances. Even the liturgical robes were decorated with bells so that their sound could drive evil forces away. 


\section{Conclusion}

The use of Greek in liturgy made the Nubian laity unable to understand it, so they turned towards alternative forms of cult. Also, little understanding of the Holy Bible caused it to be replaced by apocryphal literature with tales of miracles and the cult of saints, especially archangels obscured the service of Jesus Christ the Only Intercessor of Deliverance. The holy symbols were to protect people from both mundane and eternal evil.

However, it is hard to confirm whether 'lent, repentance and pilgrimage practices combined with prayer formulas and the allegorical understanding of cult engravings gave a feeling of penance for one's sins and hope of obtaining eternal life' (Araszczuk 169), for there are no written sources remaining.

\section{A B S T R A C T}

The study of Christian popular piety in Nubia is very difficult, because after the old Christian communities in Nubia only ruins of churches, towns and villages buried in the desert sand, which are successfully examined by archaeologists from various countries, including Poland. The article presents forms of popular piety from the areas of Nobadia and Makuria, the former Christian kingdoms in the areas of present-day Sudan. Due to the small number of sources, the Alwa kingdom was omitted. The elements presented in this article are merely an outline of popular piety, which, thanks to the research of settlement positions from the period of Christian kingdoms and epigraphical sources, is successfully reconstructed.

Keywords: Nubia; Christianity; popular piety; Christian Kingdoms in Nubia; settlement

Słowa kluczowe: Nubia; chrześcijaństwo; pobożność ludowa; chrześcijańskie królestwa w Nubii; osada

\section{BIBLIOGRAPHY}

Adams, William Yewdale. „The United Kingdom of Makuria and Nobadia. A Medieval Anomaly.” Egypt and Africa. Nubian from Prehistory to Islam. Eds. Winifred Davies. London: British Museum Press, 1993: 257-263.

Araszczuk, Stanisław. „Język i formy pobożności ludowej.”, Seminare. Poszukiwania naukowe 20 (2004): 163-179.

Atiya, Azis Suryal. History of Eastern Christianity. London: Methuen, 1968.

Brakmann, Heinzgerd. "Defunctus adhuc loquitur. Gottesdienst und Gebetsliteratur der untergegangenen Kirche in Nubien.”, Archiv Für Liturgiewissenschaft Jahrgang 48 (2006): 283-333. 
Burstein, Stanley. "When Greek Was an African Language: The Role of Greek Culture in Ancient and Medieval Nubia." Journal of History World 19.1 (2008): 41-61.

Congregation for Divine Worship and the Discipline of the Sacraments, Directory on Popular Piety and the Liturgy: Principles and Guidelines. London: The Incorporated Catholic Truth Society, 2002.

Deptuła, Agata. "An inscription with the liturgical hymn from the Lower Church in Banganarti" Polish Archaeology in the Mediterranean 20 (2012): 267-272.

Deptuła, Agata. "Inscriptions from Saint Menas' Church in Selib." Nubian Voices II: New Texts and Studies on Christian Nubian Culture (The Journal of Juristic Papyrology Supplement Series 27). Eds. Adam Łajtar, Grzegorz. Ochała, Jacques van der Vliet. Warsaw: Faculty of Law and Admistration, 2015: 119-136.

Dijkstra, Jitse Harm Fokke. Philae and the End of Ancient Egyptian Religion: A Region Study of Religious Transformation (298-642 CE). (Orientalia Lovaniensia Analecta 173). Leiden: Peeters, 2008 .

Dijkstra, Jitse Harm Fokke. Religious Encounters on the Southern Egyptian Frontier in Late Antiquity (298-642). Ph.D. Diss., Rijksuniversiteit Groningen, 2005.

Dobrzeniecki, Tadeusz. "Maiestas Crucis in the mural paintings of the Faras Cathedral. Some iconographical notes." Bulletin du Musée National de Varsovie 15 (1974): 6-20.

Donadoni, Sergio. "Les graffiti de l'église de Sonqi Tino." Nubia. Récentes recherches. Actes du colloque nubiologique international au Musée National de Varsovie, 19-22 juin 1972, Ed. Kazimierz Michałowski. Varsovie: Musée national, 1975: 31-39.

Drzewiecki, Mariusz. Mighty Kingdoms and their Forts. The Role of Fortified Sites in the Fall of Meroe and Rise of Medieval Realms in Upper Nubia. Warsaw: IKŚIO PAN, 2016.

Frend, William Hugh Clifford. "Nubia as an Outpost of Byzantine Cultural Influence." Byzantinoslavica 29.2 (1968): 319-326.

Frend, William Hugh Clifford. "The Mission to Nubia: An Episode in the Struggle for Power in Sixth Century Byzantium." Travaux du Centre d'Archeologie Mediterraneenne de l'Academie Polonaise des Sciences (Études et Travaux 8) 16 (1975): 10-16.

Gerstel, Sharon. Talbot, Alice-Mary. "The Culture of Lay Piety in Medieval Byzantium (1054-1453)." The Cambridge History of Christianity, V, Eastern Christianity. Ed. Michalel Angold. London: Cambridge University Press, 2006: 79-100.

Godlewski, Włodzimierz. Pachoras: The cathedrals of Aetios, Paulos and Petros. The architecture. (PAM Supplement Series 1). Warsaw: Warsaw University Press, 2006.

Grillmeier, Aloys. [with Hainthaler, Theresia]. Christ in Christian Tradition. vol. 2: From the Council of Chalcedon (451) to Gregory the Great (590-604). part 4: The Church of Alexandria with Nubia and Ethiopia after 451. trans. Orville Cole Dean, London: Mowbray, 1996.

Iliffe, John. Africans: The History of a Continent. (African Studies 85). Cambridge: Cambridge University Press, 1995.

Jakobielski, Stefan. Faras III: A history of the bishopric of Pachoras on the basis of Coptic inscriptions. Warszawa: Éditions Scientifiques de Pologne, 1972.

Jakobielski, Stefan. Martens-Czarnecka, Małgorzata. Łaptaś, Magdalena. Mierzejewska, Bożena. Rostkowska, Bożena. Pachoras. The Wall Paintings from the Cathedrals of Aetios, Paulos and Petros. (PAM Monograph Series 4), Warszawa: Wydawnictwa Uniwersytetu Warszawskiego, 2017.

Kopeć, Jerzy. „Liturgia i pobożność ludowa w świetle historii.” Liturgia i pobożność ludowa. Eds. Władysław Nowak. Olsztyn: Wydawnictwo Uniwersytetu Warmińsko-Mazurskiego, 2003: 25-38 .

Łajtar, Adam, "Late Christian Nubia through Visitors' inscriptions from the Upper Church at Banganarti." Between the Cataracts. Proceedings of the 11th Conference of Nubian Studies. Warsaw University, 27 August - 2 September 2006. Part 1: Main Papers (PAM Supplement Series 2.1). Eds. Włodzimierz Godlewski, Adam Łajtar, Warsaw: Warsaw University Press, 2008: 321-331. 
Łajtar, Adam. "Varia Nubica XII - XIX." Journal of Juristic Papyrology 39 (2009): 115-119.

Łajtar, Adam. Jacques, van der Vliet. "Rich Ladies of Meinarti and their Churches. With an appended list of sources from Christian Nubia containing the expression "having the Church of so-and-so"." The Journal of juristic Papyrology 28 (1998): 35-53.

Łaptaś, Magdalena. "Archangels as Protectors and Guardians in Nubian Art." Between the Cataracts. Proceedings of the $11^{\text {th }}$ Conference of Nubian Studies. Warsaw University, 27 August - 2 September 2006. Part 2, fasc. 2: Session Papers (PAM Supplement Series 2.2/2). Eds. Włodzimierz Godlewski, Adam Łajtar, Warsaw: Warsaw University Press, 2010: 675-682.

Łaptaś, Magdalena. „A Feast of the Archangel Michael. A New Interpretation of the Mural Painting from Old Dongola." Eastern Christian Art 5 (2008b): 75-85.

Łaptaś, Magdalena. „Symbolika oczu na skrzydłach archaniołów w malarstwie nubijskim.” Initium sapientiae humilitas. Studia ofiarowane Profesorowi Jakubowi Pokorze z okazji 70. urodzin. Eds. Zbigniew Bania, Anna Sylwia Czyż, Janusz Nowiński. Warszawa: Uniwersytet Kardynała S. Wyszyńskiego, 2015: 42-55.

Martens-Czarniecka, Małgorzata. "The Christian Nubia and the Arabs." Studia Ceranea 5 (2005): 249-265.

Martens-Czarniecka, Małgorzata. The Wall Paintings from the Monastery on Kom H in Dongola, Nubia III, Dongola III. (PCMA Monograph Series 3). Warsaw: PCMA, Warsaw University Press, 2012a.

Martens-Czarniecka, Małgorzta. "Iconography of Jesus Christ in Nubian Painting." Études et Travaux 25 (2012b): 242-252.

Mich, Katarzyna Anna. „Problem zakorzenienia chrześcijaństwa w lokalnej kulturze Nubii a język liturgii Kościoła nubijskiego.” Sudan wojna, polityka, uchodźcy. Eds. Waldemar Cisło, Jarosław Różański, Maciej Ząbek. Pelplin: Wydawnictwo „Bernardinum”, 2016. 73-94.

Michałowski, Kazimierz. Die Kathedrale aus dem Wüstensand. Einsiedeln-Zürich-Köln: Benziger Verlag, 1967.

Mierzejewska, Bożena., Faras Gallery. Guide. Warsaw: The National Museum in Warsaw, 2014.

Ostrowski, Maciej. "Kilka refleksji teologicznych i duszpasterskich wokół pielgrzymowania jako formy pobożności ludowej." Gospodarka i przestrzeń, prace dedykowane Profesor Danucie Ptaszyckiej-Jackowskiej. Eds. Bolesław Domański, Włodzimierz Kurek. Kraków: Wydawnictwo IGiGP Uniwersytetu Jagiellońskiego, 2009: 215-226.

Stark, Robert J. Ciesielska, Joanna. A. "Cemetery 4 at Ghazali (Sudan): Excavations during the Fall 2016 Season." Bayuda Studies. Proceedings of the First International Conference on the Archaeology of the Bayuda Desert in Sudan. (Meroitica -Schriften zur altsudanesischen Geschichte und Archäologie 27). Eds. Angelika Lohwasser, Tim Karberg, Johannes Auenmüller, Wiesbaden: Harrassowitz, 2018: 273-285.

Timothy. „The Discourse on Saint Michael the Archangel by Timothy, Archbishop of Alexandria.” Miscellaneous Coptic Texts in the Dialect of Upper Egypt. Ed., trans. Ernest Alfred Wallis Budge, London: Sold at the British Museum and by Longmans and Co., 1915: 1029, 519-520;

Vandenbeusch, Marie Antoine, Daniel. "Under Saint Michael's Protection: A Tattoo from Christian Nubia." Journal of the Canadian Centre for Epigraphic Documents 1 (2015): 15-19.

Vantini, Giovanni. „Christian Relics in Sudanese Tradition.” Nubia Christiana 1 (1982): 25-39.

Welsby, Derek. Medieval Kingdoms of Nubia. Pagans, Christians and Muslims along the Middle Nile. London: The British Museum Press, 2002.

Zielińska, Dobrochna. "The iconographical program in Nubian churches: progress report based on a new reconstruction project." Between the Cataracts. Proceedings of the 11th Conference of Nubian Studies. Warsaw University, 27 August - 2 September 2006. Part 2, fasc. 2: Session Papers (PAM Supplement Series 2.2/2). Eds. Włodzimierz Godlewski, Adam Łajtar, Warsaw: Warsaw University Press, 2010: 643-652.

Żurawski, Bogdan. "Churches of Banganarti, 2002-2006." Between the Cataracts. Proceedings of the $11^{\text {th }}$ Conference of Nubian Studies. Warsaw University, 27 August - 2 September 2006. 
Part 1: Main Papers (PAM Supplement Series 2.1). Eds. Włodzimierz Godlewski, Adam Łajtar, Warsaw: Warsaw University Press, 2008: 303-320.

Żurawski, Bogdan. „Magica et ceramica: magic and ceramics in Christian Nubia.”, Archaeologia Polona 30 (1992): 87-107.

Żurawski, Bogdan. "Faith healing, philanthropy and commemoration in Late Christian Dongola." Ägypten und Nubien in spätantiker und christlichen Zeit. Akten des 6. Internationalen Koptologenkongresses Münster, 20-25. Juli 1996, Band I, Materielle Kultur, Kunst und religiöses Leben. Eds. Stephen Emmel, Wiesbaden: Reichert Verlag 1999, 423-448.

Żurawski, Bogdan. „Peregrinatio nubiana. Kilka uwag na marginesie problematyki miejsc świętych w Nubii chrześcijańskiej”. Sympozja Kazimierskie. Miejsca święte w epoce późnego antyku. T. 5. Eds. Bożena Iwaszkiewicz-Wronikowska, Daniel. Próchniak. Lublin: Towarzystwo Naukowe KUL, Katolicki Uniwersytet Lubelski Jana Pawła II, 2005, s. 301-325.

Żurawski, Bogdan. Kings and Pilgrims. St Raphael Church II at Banganarti, mid-eleventh to mid-eighteenth century. Nubia V, Banganarti 2. Warsaw: Wydawnictwo Neriton / IKSiO PAN, 2014.

Żurawski. Bogdan. St Raphael Church I at Banganarti mid-sixth to mid-eleventh century. An introduction to the site and the epoch. Nubia IV, Banganarti 1. (Gdansk Archaeological Museum African Reports 10, 2012, Monograph Series 2). Gdansk: Muzeum Archeologiczne w Gdańsku, Centrum Archeologii Śródziemnomorskiej UW, Instytut Kultur Śródziemnomorskich i Orientalnych PAN, 2012.

Katarzyna Anna Mich, absolwentka archeologii i teologii na Uniwersytecie im. Adama Mickiewicza w Poznaniu. Doktorantka misjologii w Instytucie Dialogu i Kultury na Uniwersytecie Kardynała Stefana Wyszyńskiego w Warszawie. W latach 2010-2016 zaangażowana w prace Akademickiego Koła Misjologicznego w Poznaniu. W latach 2014/2015 prezes Koła. 